\title{
High Resolution RP-HPLC Method for the Determination of Nevirapine and Associated Impurities
}

\author{
PHANI R.S.CH ${ }^{1 *}$, K.R.S. PRASAD ${ }^{1}$ and USENI REDDY MALLU \\ 'Department of Chemistry, K.L. University, Vaddeswaram-522502, Andhra Pradesh, India. \\ ${ }^{2}$ R.V.Labs, Guntur-522007, Andhra Pradesh, India. \\ ${ }^{*}$ Corresponding author E-mail: phani.r.s.ch@gmail.com \\ http://dx.doi.org/10.13005/ojc/320246
}

(Received: January 01, 2016; Accepted: February 17, 2016)

\begin{abstract}
Objective of the present research work is to develop a sensitive, selective and accurate new RPHPLC method with UV detection and determination for estimation of Nevirapine (NVP)and its impurities in bulk drug. The separation and quantification was achieved with Kromosil C18 isocratic column, (150 mm $\times 4.6 \mathrm{~mm}$ i.d., particle size $3.5 \mu \mathrm{m}$, maintained at ambient temperature), HPLC system (Peak LC P7000), a mixture of $20 \%$ acetonitrile, $80 \%$ buffer (sodium per chlorate) (v/v), at $\mathrm{pH}$ of 4.8 and the flow rate was set at $1.0 \mathrm{ml} / \mathrm{min}$. and $\mathrm{UV}$ detection at $220 \mathrm{~nm}$. The retention time for NVP, Impurity-A and Impurity-B were found to be 5.5, 7.8, 3.4 min respectively. The method was validated for Linearity, Accuracy, and Precision. The Limit of detection of NVP, Impurity-A and Impurity-B were found to be $0.03,0.03,0.03(\mu \mathrm{g} / \mathrm{ml})$ respectively.
\end{abstract}

Keywords: Nevirapine, ICH guidelines, RP-HPLC, RS Method, Validation.

\section{INTRODUCTION}

NVP is a non-nucleoside reverse transcriptase inhibitor used to treat HIV-1 and AIDS. Possible side effects of NVP are Diarrhea, headache, mild nausea or stomach pain, tiredness, vomiting. Some severe allergic reactions like rash, tightness in the chest, swelling of the mouth, face, lips, or tongue, itching, hives, difficulty breathing.

\section{MATERIALS AND METHODS}

Pure forms (Above 99\%) of NVP and Impurity-A, Impurity-B were obtained as gift samples from Hetero Labs, Hyderabad, India. HPLC grade solvents (Methanol, Acetonitrile, water) were procured from Merck, Mumbai, India. The mobile phase and all the solutions were filtered through a $0.45 \mathrm{~mm}$ membranes prior (Merckmillipore) to use. Per chloric acid was purchased from S.D. Fine Chem Ltd., Mumbai, India.

\section{Preparation of Mobile phase}

Acetonitrile and Sodium per chlorate $(\mathrm{pH}$ : 4.8) were taken in20:80 ratio and mixed well. The $\mathrm{pH}$ of the solution was adjusted to 4.8 with Perchloric acid. The prepared mobile phase was filtered through $0.45 \mathrm{~mm}$ filter membrane. 


\section{Preparation of stock solutions}

1. NVP stock solution: $10 \mathrm{mg}$ of NVP drug was dissolved in $100 \mathrm{ml}$ Acetonitrile to obtain $100 \mu \mathrm{g} / \mathrm{ml}$.

2. Impurity-A stock solution: $20 \mathrm{mg}$ of standard Impurity-A was dissolved in $100 \mathrm{ml}$ Acetonitrile to obtain $200 \mu \mathrm{g} / \mathrm{ml}$

3. Impurity-B stock solution: $20 \mathrm{mg}$ of standard Impurity-B was dissolved in $100 \mathrm{ml}$ Acetonitrile to obtain $200 \mu \mathrm{g} / \mathrm{ml}$

\section{Preparation of standard solutions}

$0.5 \mathrm{ml}$ of standard stock and $0.5 \mathrm{ml}$ of impurities stock solutions are taken in to $100 \mathrm{ml}$ volumetric flask and make up to $100 \mathrm{ml}$ with Acetonitrile to obtain $0.5 \mathrm{ppm}$ of NVP and 1ppm of impurity-A and impurity-B. The standard concentration equal to unknown impurity spec $(0.1 \%)$ and impurity-A and $\mathrm{B}$ concentration equal to $0.2 \%$ (as per USP limit)

\section{Preparation of sample solution}

$50 \mathrm{mg}$ of API sample taken in to $100 \mathrm{ml}$ of Acetonitrile to obtain $500 \mu \mathrm{g} / \mathrm{ml}$ concentration sample solution.

\section{Apparatus and chromatographic condition}

The method was developed and validated with HPLC system (Peak LC P7000) with isocratic pump, manual rheodyne injector with $20 \mu \mathrm{L}$ volume loop and UV- VIS detector(UV7000) and PEAK Chromatographic version 1.06 . The API and impurity were scanned with UV-Visible spectrophotometer Tech comp UV2301 with Hitachi software. Kromasil C18 column $(100 \mathrm{~mm} \times 4.6 \mathrm{~mm} \times 3.5 \mu) \mathrm{RP}-18 \mathrm{HPLC}$ column $(150 \times 4.6 \mathrm{~mm}, 3.5$ micron) was used for separation. HPLC detector wavelength was fixed at $220 \mathrm{~nm}$. Analysis was performed at ambient temperature.

\section{RESULTS AND DISCUSSION}

The aim of this work is to develop a RPHPLC method to quantify NVP and Impurity-A, Impurity-Bin Bulk drug. Previously few methods[519] are available for analysis of NVP in formulations and bulk drug.Ch Venkata Reddiah et $a^{R O}$ reported one HPLC method for analysis of NVP and its impurities. While developing method at initial stage of the methoddevelopment trials done with $\mathrm{NH}_{4} \mathrm{H}_{2} \mathrm{PO}_{4}$ Sodium per chlorate buffer solution at different $\mathrm{pH}$ and acetonitrile as solvent and C18 column but the separation of NVP and Impurity-Ais not good. Finally the best separation with good elution was achieved with Sodium per chlorate and acetonitrile at $\mathrm{pH}$ 4.8.Diluent and standard solution represented infigure-2 and 3. NVP and Impurity-A, Impurity-B are well separated and the peak shape, tailing factor (less than 2.0) and resolution also within the limit.

System suitability is an important test of method development of analytical procedures. System suitability test parameters are established for the developed method. Freshly prepared standard solution in to the system for three replicate injections (at $10 \mu \mathrm{g} / \mathrm{ml}, 20 \mu \mathrm{g} / \mathrm{ml}, 30 \mu \mathrm{g} / \mathrm{ml}$ ) and calculated the percentage relative standard deviation(RSD) for area and retention time and the results found to be satisfactory. Three replicate standard solution results tabulated the results in table.1.<smiles>Cc1ccnc2c1NC(=O)c1cccnc1N2C1CC1</smiles>

Nevirapine(NVP)<smiles>CCN1c2ncccc2C(=O)Nc2c(C)ccnc21</smiles>

Impurity-1 (Compound-A)<smiles>Cc1ccnc2c1NC(=O)c1cccnc1N2</smiles>

Impurity-2 (Compound-B)

Fig.1: Chemical structure of NVP and its Impurities 


\section{Method validation}

Once the HPLC method development was over, validated the developed method as perlCH and FDA ${ }^{[1-5]}$ guidelines with parameters like, linearity, precision, accuracy and range, ruggedness, robustness etc.

Precision of the developed method was evaluated by carrying out six different sample preparations for all individual and combination products. Percentage relative standard deviation (\% RSD) was found to be less than $1 \%$ for within a day and day to day variations, which proves that that method is precise. Results were shown in Table-2.

For linearity test the standard solution was taken as $100 \%$ concentration and linearity range was fixed $25 \%, 50 \%, 75 \%, 100 \%, 125 \%, 150 \%$. $200 \%$ Linearity solutions are prepared from stock solutions and standard solution by serial dilution. The linearity results were given in Table.3. The linearity graph was shown in Graph.1, Graph.2 and Graph.3.

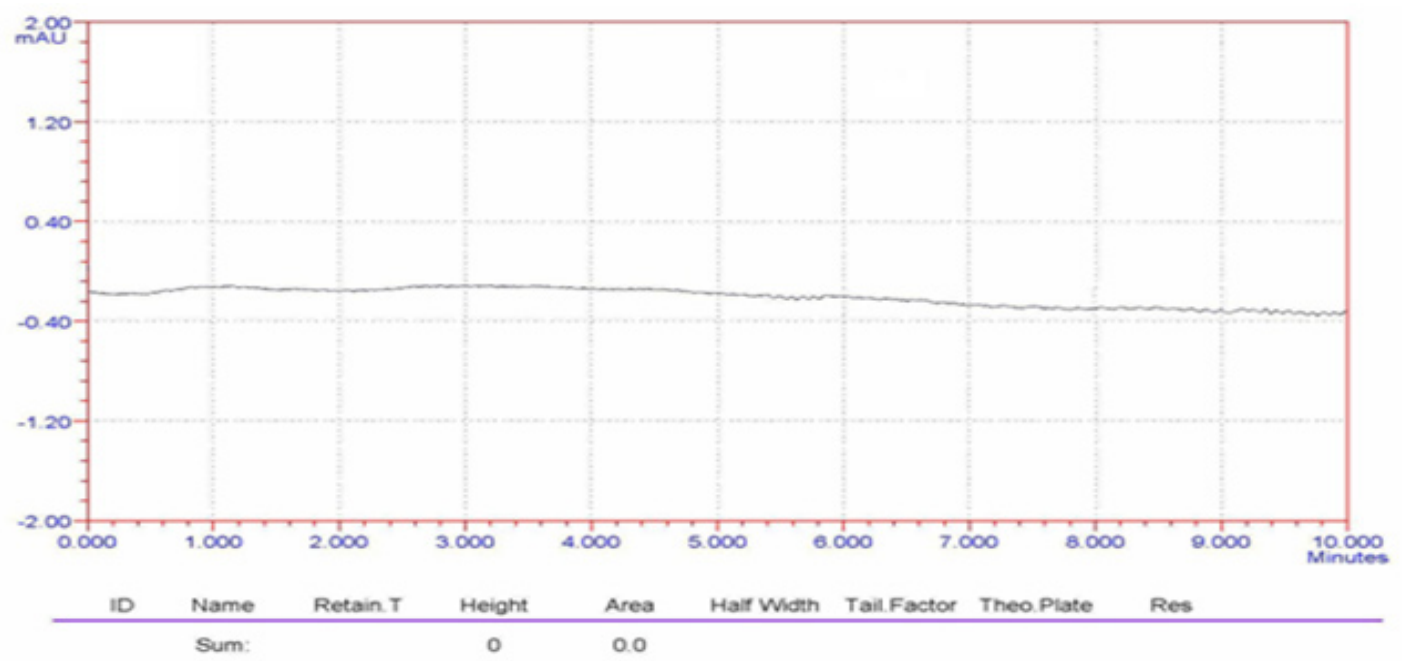

Fig. 2: Representative chromatogram of blank

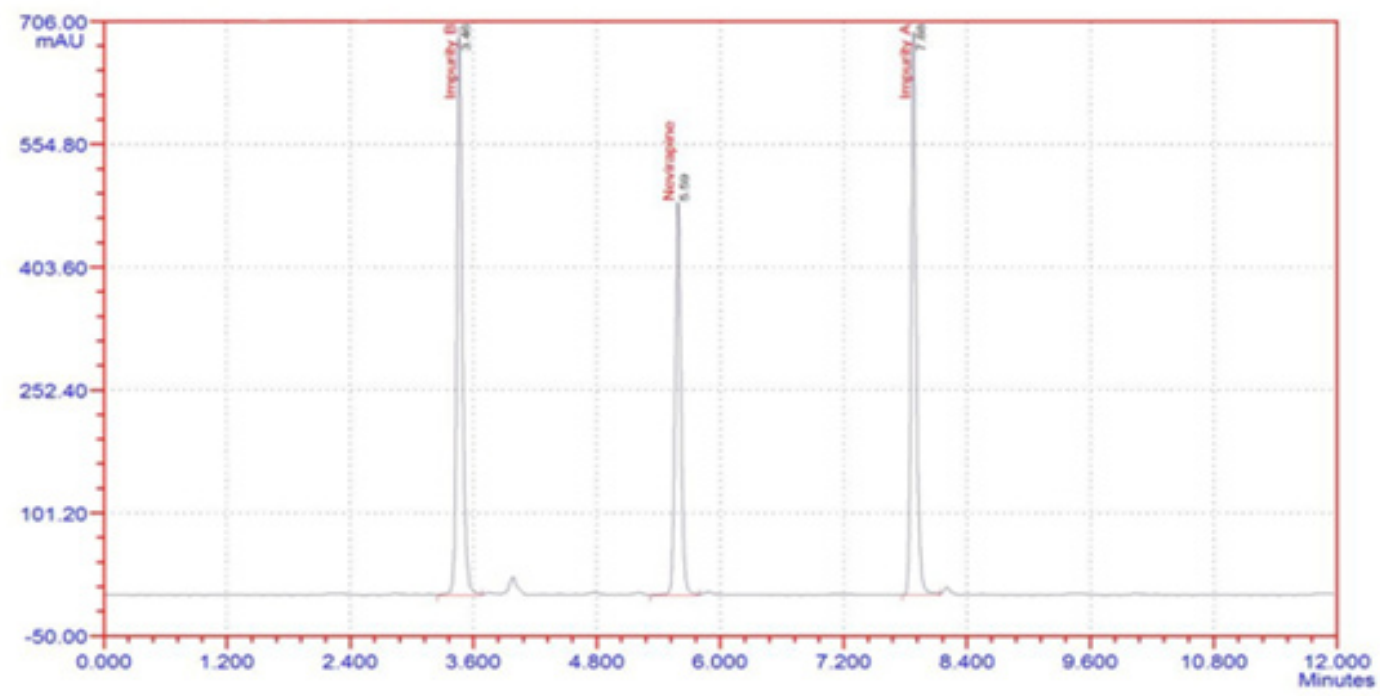

Fig. 3: Representative Standard chromatogram with NVP, Impurity-A, Impurity-B 
The ruggedness of the method was determined by carrying out the experiment on other HPLC by different Analysts using different columns of similar types. The percentage RSD of six different preparations assay values with two different instruments, analysts and columns were given in table.4. Robustness of the method was determined by making small changes in the chromatographic conditions and found to be unaffected by small changes like $p H$ changes \pm 0.1 , flow rate $\pm 1 \%$, wavelength $\pm 2 \mathrm{~nm}$, temperature $\pm 2^{\circ} \mathrm{C}$, and $\pm 2 \%$ change in organic solvent in the mobile phase. The Robustness results are shown in the Table 5.The
LOQ and LOD concentrations of developed method are given in Table.4Analysis of NVP, Impurity-A, Impurity-B in analyzed in NVP Bulk drug by using developed HPLC method. The chromatogram was given shown in Figure. 4

\section{Forced degradation studies}

$50 \mathrm{mg}$ of NVP was diluted in $100 \mathrm{ml}$ of 0.1 $\mathrm{N} \mathrm{HCl}$. and heated up to $400^{\circ} \mathrm{C} .50 \mathrm{mg}$ of NVP was diluted in $100 \mathrm{ml}$ of $0.1 \mathrm{NaOH}$ and heated up to $400^{\circ} \mathrm{C} .50 \mathrm{mg}$ of NVP was taken in $50 \mathrm{ml}$ of $\mathrm{H}_{2} \mathrm{O}_{2}$ and make up to $100 \mathrm{ml}$ with diluents. The three prepared solutions are injected and calculated percentage of

Table 1: System suitability test results of NVP, Impurity-A, Impurity-B

\begin{tabular}{|c|c|c|c|c|c|c|}
\hline \multicolumn{7}{|c|}{ System suitability of NVP } \\
\hline $\begin{array}{l}\text { No of } \\
\text { Injections }\end{array}$ & $\begin{array}{l}\text { Concentraion } \\
\quad(\mu \mathrm{g} / \mathrm{ml})\end{array}$ & R.T & Resolution & T. Plates & $\begin{array}{l}\text { Tailing } \\
\text { Factor }\end{array}$ & Peak Area \\
\hline 1 & 10 & 5.509 & 16.24 & 26581 & 1.22 & 69812 \\
\hline 2 & 10 & 5.505 & 16.31 & 27371 & 1.16 & 65957 \\
\hline 3 & 10 & 5.490 & 15.83 & 27005 & 1.18 & 67781 \\
\hline 1 & 20 & 5.492 & 15.78 & 26585 & 1.22 & 91533 \\
\hline 2 & 20 & 5.497 & 16.01 & 27279 & 1.20 & 76300 \\
\hline 3 & 20 & 5.517 & 16.27 & 26586 & 1.20 & 76609 \\
\hline 1 & 30 & 5.525 & 16.08 & 26723 & 1.18 & 98420 \\
\hline 2 & 30 & 5.515 & 15.89 & 26609 & 1.12 & 96883 \\
\hline 3 & 30 & 5.503 & 16.00 & 27055 & 1.15 & 95925 \\
\hline \multicolumn{7}{|c|}{ System suitability of Impurity-A } \\
\hline 1 & 10 & 7.847 & 17.75 & 59757 & 1.73 & 67747 \\
\hline 2 & 10 & 7.852 & 17.55 & 54625 & 1.64 & 67779 \\
\hline 3 & 10 & 7.852 & 17.72 & 55822 & 1.59 & 70602 \\
\hline 1 & 20 & 7.825 & 17.63 & 57987 & 1.60 & 84307 \\
\hline 2 & 20 & 7.857 & 17.96 & 58670 & 1.61 & 81767 \\
\hline 3 & 20 & 7.839 & 17.52 & 58453 & 1.62 & 84501 \\
\hline 1 & 30 & 7.857 & 17.70 & 60075 & 1.56 & 101203 \\
\hline 2 & 30 & 7.850 & 17.26 & 53905 & 1.67 & 103745 \\
\hline 3 & 30 & 7.850 & 17.78 & 58217 & 1.60 & 103959 \\
\hline \multicolumn{7}{|c|}{ System suitability of Impurity-B } \\
\hline 1 & 10 & 3.305 & 0.0 & 9423 & 1.35 & 83795 \\
\hline 2 & 10 & 3.293 & 0.0 & 9106 & 1.40 & 80442 \\
\hline 3 & 10 & 3.307 & 0.0 & 8639 & 1.37 & 90287 \\
\hline 1 & 20 & 3.302 & 0.0 & 8533 & 1.37 & 83795 \\
\hline 2 & 20 & 3.303 & 0.0 & 8789 & 1.39 & 80442 \\
\hline 3 & 20 & 3.274 & 0.0 & 8689 & 1.35 & 90287 \\
\hline 1 & 30 & 3.302 & 0.0 & 8943 & 1.39 & 114618 \\
\hline 2 & 30 & 3.303 & 0.0 & 8897 & 1.38 & 103693 \\
\hline 3 & 30 & 3.274 & 0.0 & 8962 & 1.33 & 108958 \\
\hline
\end{tabular}


Table 2: Precision results of NVP, Impurity-A, Impurity-B

\begin{tabular}{lccc}
\hline Injections & NVP & Impurity-A & Impurity-B \\
\hline 1 & 13996 & 17124 & 16511 \\
2 & 14167 & 17306 & 16553 \\
3 & 13845 & 17098 & 16498 \\
4 & 14128 & 17185 & 16435 \\
5 & 13855 & 17254 & 16584 \\
6 & 13871 & 17068 & 16472 \\
$\%$ RSD & 0.936 & 0.495 & 0.298 \\
\hline
\end{tabular}

degradation. Degradation peaks of NVP at different conditions are shown in Figure.7 to Figure.9.

\section{CONCLUSION}

The method was developed at $220 \mathrm{~nm}$ UV-Wave length. The mobile phase was fixed as Aceteonitrile and Buffer on the basis of drug solubility. The ratio of organic solvent and buffer was confirmed on trail and error basis. $\mathrm{NH}_{4} \mathrm{H}_{2} \mathrm{PO}_{4}$ and Perchloric acid are used as buffer. Method was finally developed with Perchloric acid at $p H$ 4.8. The method

Table 3: Linearity results of NVP, Impurity-A, Impurity-B

\begin{tabular}{lccc}
\hline $\begin{array}{l}\text { Percentage of } \\
\text { Concentration }\end{array}$ & NVP & Impurity-A & Impurity-B \\
\hline $25 \%$ & 9587 & 11334 & 9668 \\
$50 \%$ & 10851 & 13559 & 12568 \\
$75 \%$ & 12574 & 15451 & 14689 \\
$100 \%$ & 13841 & 17239 & 16626 \\
$125 \%$ & 15345 & 18885 & 19224 \\
$150 \%$ & 16629 & 20975 & 21277 \\
$200 \%$ & 18316 & 23140 & 23974 \\
$y=m x+c$ & $y=11750 x+8039$ & $y=7800 x+9458$ & $y=9394 x+7498$ \\
Co-relation & 0.998 & $r 2=0.998$ & 0.998 \\
Coefficient & & & \\
\hline
\end{tabular}

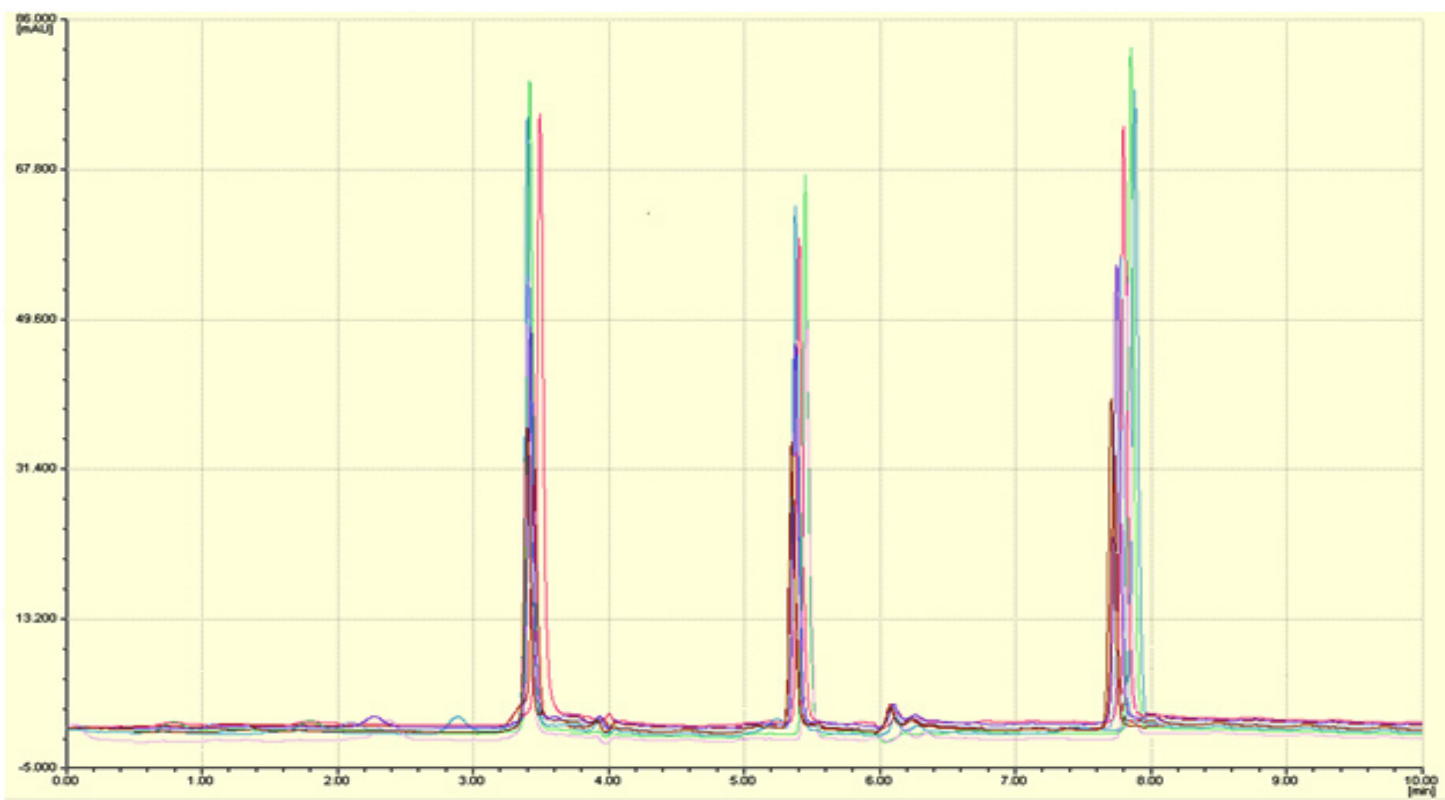

Fig.4: Linearity overlaid Chromatograms 


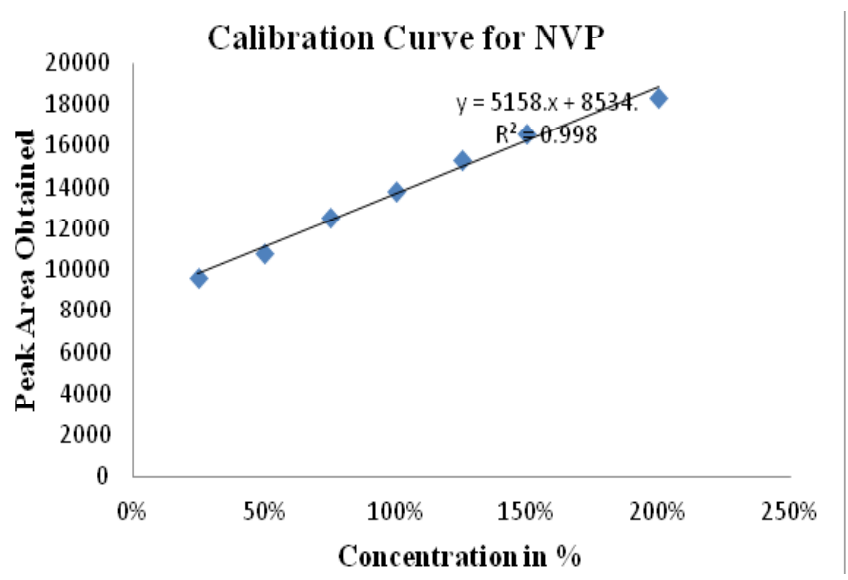

Graph 1: linearity graph of NVP

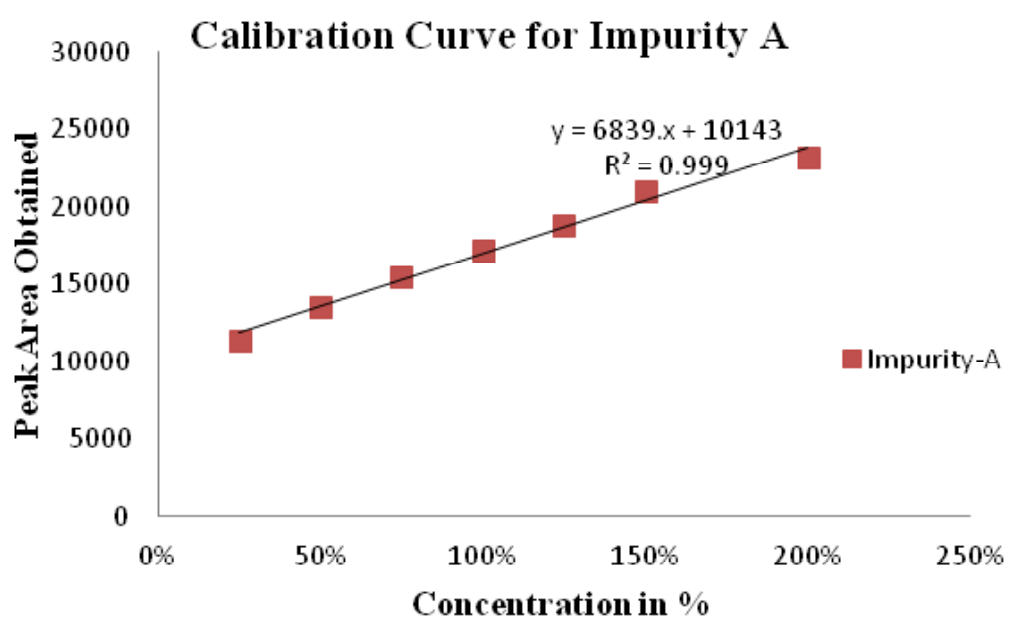

Graph 2: linearity graph of Impurity-A

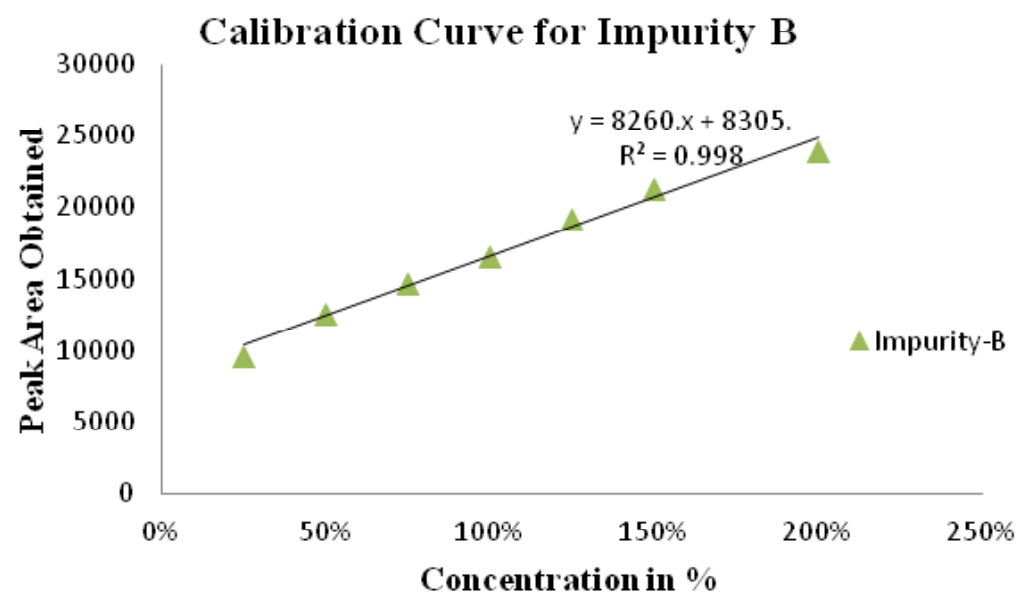

Graph 3: linearity graph of Impurity-B 


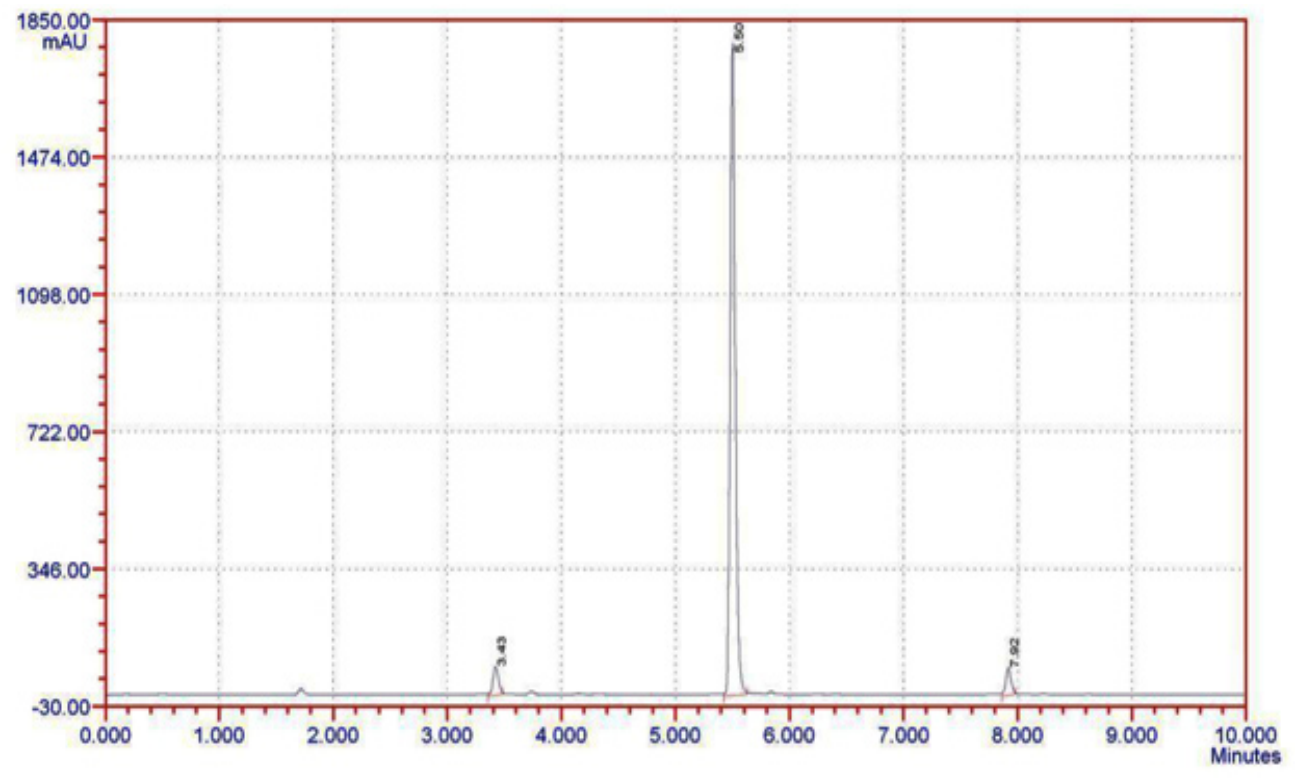

Fig. 5: Representative Sample chromatogram of NVP, Impurity-A, Impurity-B

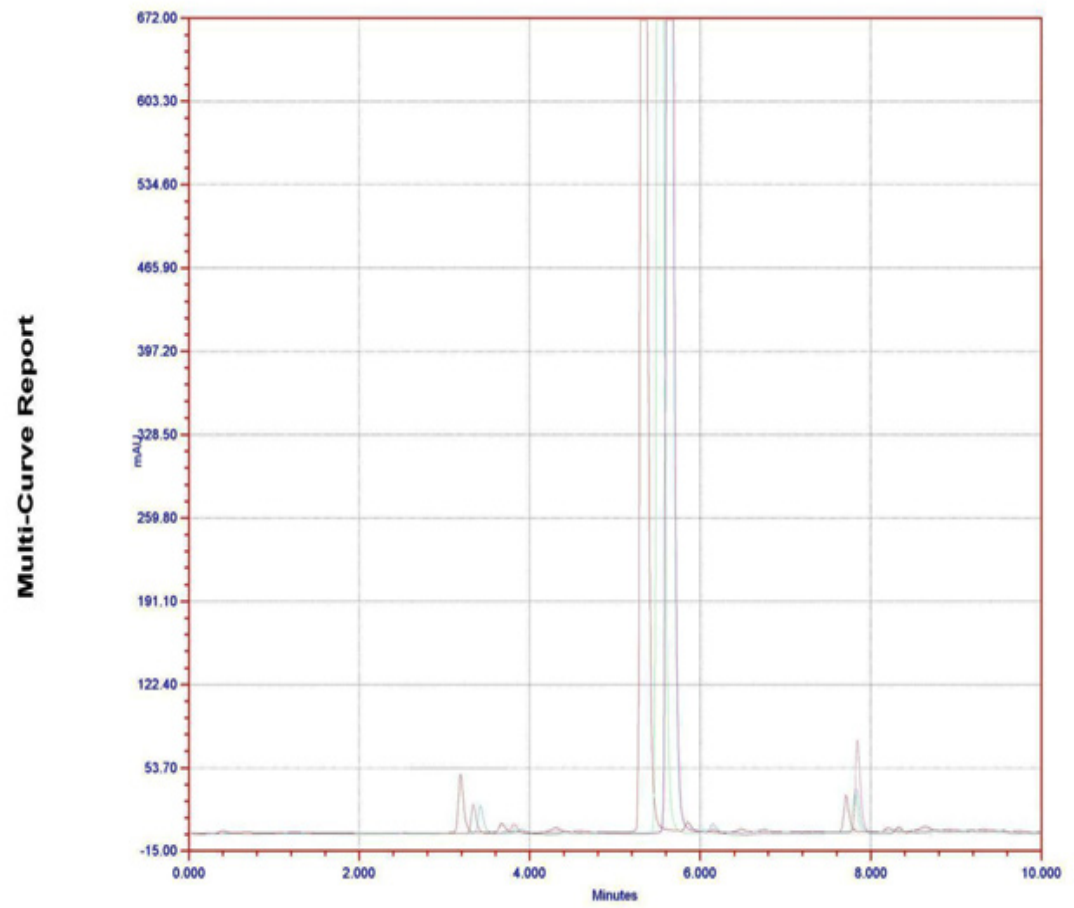

Fig. 6: Representative Degradation overlaid chromatogram of NVP 
Table 4: Ruggedness results

\begin{tabular}{lccc}
\hline & Ruggedness & & \\
Test & NVP & Imp-A & Imp-B \\
\hline Standard solution Area & 13996 & 17124 & 16511 \\
Mean of Ruggedness Six injections peak area & 13856 & 16971 & 16418 \\
Percentage of Change in peak area & $1.000 \%$ & $0.893 \%$ & $0.563 \%$ \\
\hline
\end{tabular}

Table 5: Robustness results

\begin{tabular}{|c|c|c|c|c|c|c|}
\hline \multirow[b]{2}{*}{ Change in Parameter } & \multirow[b]{2}{*}{ NVP } & \multicolumn{2}{|c|}{ Robustness } & \multirow[b]{2}{*}{$\begin{array}{l}\text { Percentage } \\
\text { of Change } \\
\text { in peak area }\end{array}$} & \multirow[b]{2}{*}{ Imp-B } & \multirow[b]{2}{*}{$\begin{array}{c}\text { Percentage } \\
\text { of Change } \\
\text { in peak area }\end{array}$} \\
\hline & & $\begin{array}{c}\text { Percentage } \\
\text { of Change } \\
\text { in peak area }\end{array}$ & Imp-A & & & \\
\hline Standard solution Area & 13996 & 0.000 & 17124 & 0.000 & 16511 & 0.000 \\
\hline$p \mathrm{H}$ at 4.6 & 13745 & 1.793 & 16954 & 0.992 & 16452 & 0.537 \\
\hline$p \mathrm{H}$ at 4.9 & 13895 & 0.721 & 16977 & 0.858 & 16398 & 0.684 \\
\hline flow rate at $1.1 \mathrm{ml} / \mathrm{min}$ & 13915 & 0.578 & 17049 & 0.437 & 16477 & 0.205 \\
\hline flow rate at $0.9 \mathrm{ml} / \mathrm{min}$ & 13887 & 0.778 & 17138 & 0.081 & 16402 & 0.660 \\
\hline wavelength $222 \mathrm{~nm}$ & 13752 & 1.743 & 17089 & 0.204 & 16582 & 0.430 \\
\hline wavelength $218 \mathrm{~nm}$ & 13790 & 1.471 & 17055 & 0.402 & 16601 & 0.545 \\
\hline
\end{tabular}

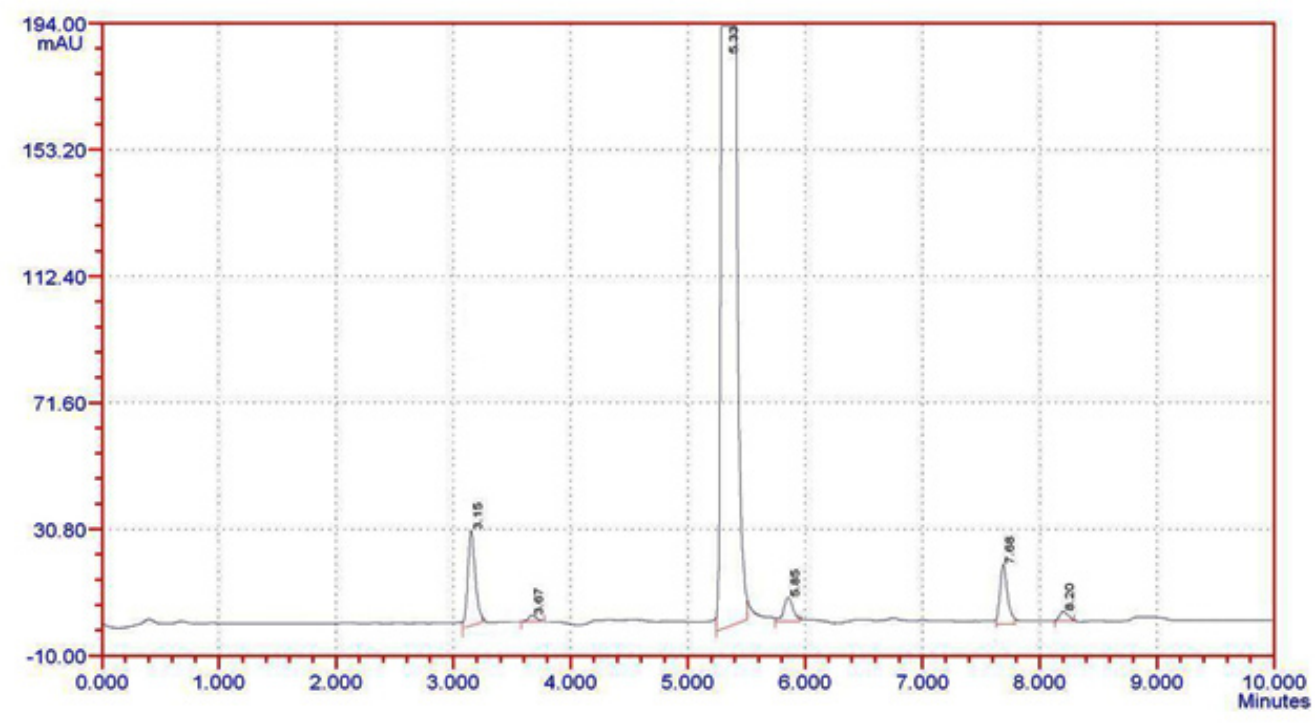

Fig. 7: Representative Acid degradation chromatogram of NVP 


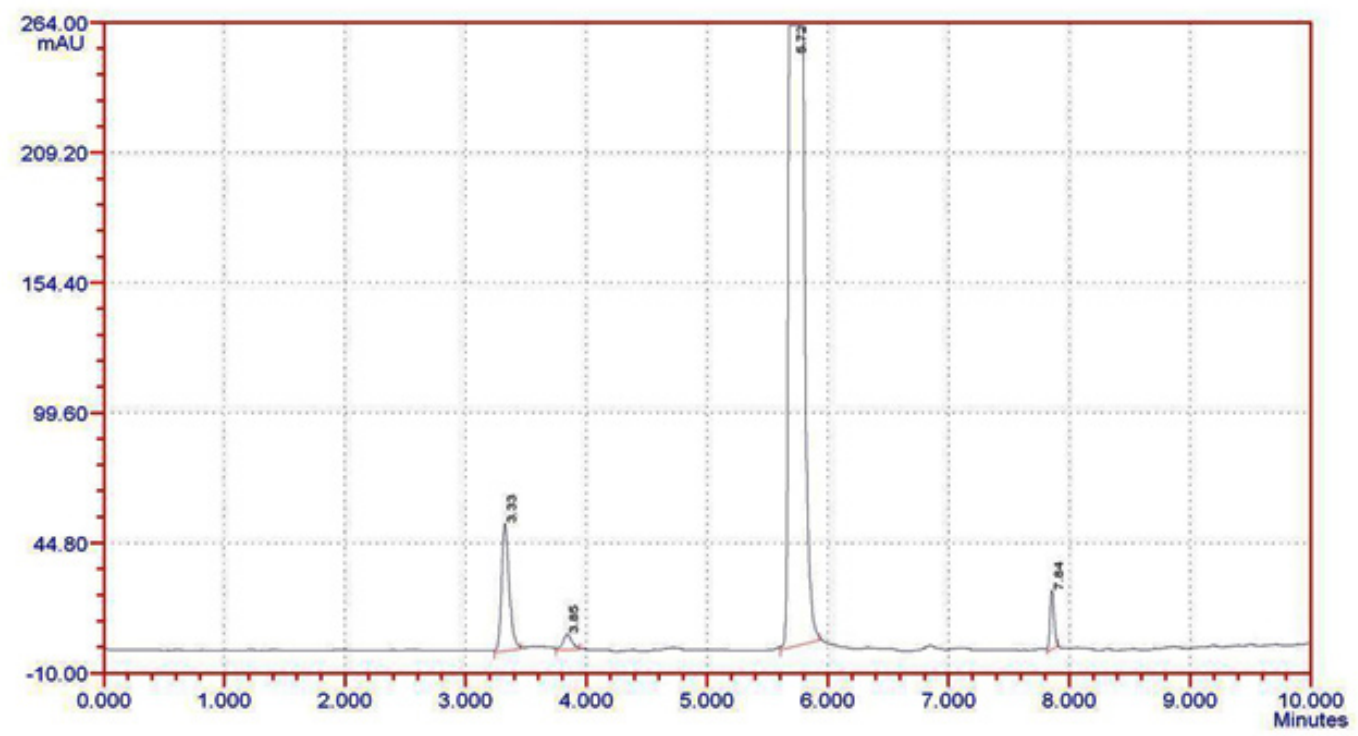

Fig. 8: Representative Basic degradation chromatogram of NVP

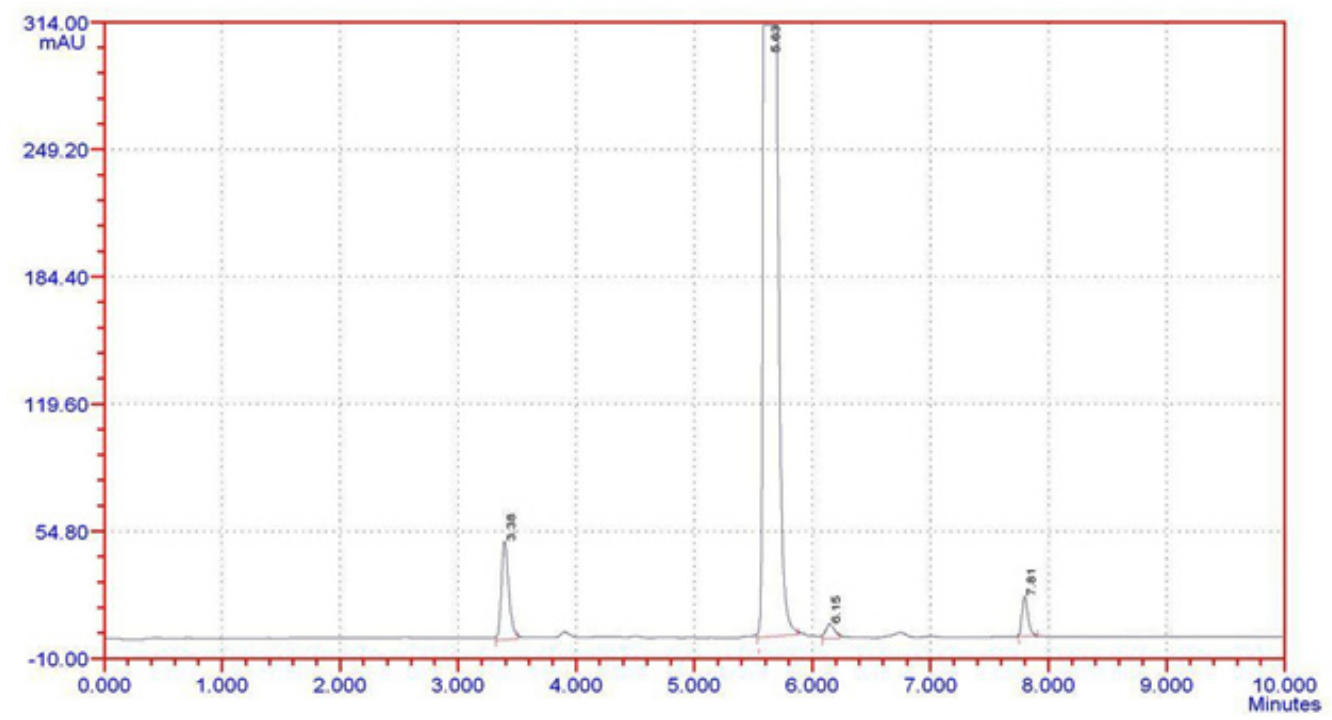

Fig. 9: Representative Peroxide degradation chromatogram of NVP

Table.6: The LOQ and LOD concentrations of NVP, Impurity-A, Impurity-B

\begin{tabular}{llccc}
\hline S.No & Parameter & NVP & Imp-A & Imp-B \\
\hline 1 & LOQ $(\mu \mathrm{g} / \mathrm{ml})$ & 0.1 & 0.1 & 0.1 \\
2 & LOD $(\mu \mathrm{g} / \mathrm{ml})$ & 0.03 & 0.03 & 0.03 \\
\hline
\end{tabular}

was validated according to $\mathrm{ICH}$ guidelines. There us no interference in blank injection. The precision RSD of NVP, Impurity-A, Impurity-B are below 1.0 The linearity range was fixed between $25 \%$ to $200 \%$. The correlation coefficient is 0.998 . The ruggedness and robustness tests are passed. The L.O.Q ranges of NVP, Imp-A and IMP-B are $0.1 \mu \mathrm{g} / \mathrm{ml}$ and LOD ranges are $0.03 \mu \mathrm{g} / \mathrm{ml}$. The NVP degradation study 
Table 7: Degradation study results of NVP, Impurity-A, Impurity-B

\begin{tabular}{lccccc}
\hline $\begin{array}{l}\text { S. } \\
\text { No. }\end{array}$ & Degrading Agent & Drug & $\begin{array}{c}\text { Initial concentration } \\
\text { of drug before } \\
\text { degradation }(\boldsymbol{\mu g} / \mathbf{m l})\end{array}$ & $\begin{array}{c}\text { Final concentration } \\
\text { of drug after } \\
\text { degradation }(\mathbf{i g} / \mathrm{ml})\end{array}$ & $\begin{array}{c}\% \text { of } \\
\text { Degradation }\end{array}$ \\
\hline 1 & No degrading agent & $\mathrm{NVP}$ & 1195565 & 1195565 & 0.00 \\
2 & $0.1 \mathrm{~N} \mathrm{HCL}$ & $\mathrm{NVP}$ & 1195565 & 1087081 & 9.07 \\
3 & $0.1 \mathrm{M} \mathrm{NaOH}$ & $\mathrm{NVP}$ & 1195565 & 1140772 & 4.58 \\
4 & $50 \% \mathrm{H}_{2} \mathrm{O}_{2}$ & $\mathrm{NVP}$ & 1195565 & 893682 & 25.25 \\
\hline
\end{tabular}

was carried out at three conditons.NVP 25.25\% degraded in peroxide condtion.9.07\% degraded in Acidic condition. $4.58 \%$ degraded in Basic condition. The developed RPHPLC method was validated with precision, linearity, accuracy and proved to be sensitive and effective for the determination of NVP and its relative substances (Impurity-A, Impurity-B) during stability testing of the bulk drug. We can apply this method for routine quality control analysis in bulk drug manufacturing industries.

\section{REFERENCES}

1. Sweetman S.C., Martindale, The Complete Drug Reference, Edn. 33, Pharmaceutical Press,London, 2002.

2. Montvale N J, Physician's Desk Reference, Edn.56, Medical Economics Company Inc,Montvale, 2003.

3. International Conference on Harmonization, Q2A: Text on Validation of Analytical Procedures, Federal Register, 1995, 60(40), 11260-11262. 48.

4. Validation of Analytical Procedures, Text And Methodology Q2(R1), Federal Register, 1997, 62( 96) p. 27463-7

5. Kapoor N, Khandavilli S, Panchagnula R. Simultaneous determination of lamivudine, stavudine and nevirapine in antiretroviral fixed dose combinations by high performance liquid chromatography. Analytica Chimica Acta,2006, 570:41-5

6. Anantha Kumar D, Naveen Babu MN, SeshagiriRao JVLN, JayathirthRao V. Simultaneous determination of lamivudine, zidovudine and nevirapine in tablet dosage forms by RP-HPLC method. Rasayan Journal of Chemistry, 2010, 3:94-9.

7. Md. S. Maqsood Ahmed, J. Sudhakar Reddy, I.E. Chakravarth,K. Prabhavathi, A simple spectrophotometric determination of Nevirapine in pharmaceutical dosage form ,
J. Chem. Pharm. Res. 2011, 3(4):172-176.

8. Anjali Joshi, Moji ChristianahAdeyeye. Reversed Phase LC-UV Method Development and Validation for Simultaneous determination of three antiretroviral: lamivudine, zidovudine, nevirapine and possible degradants in a Fixed Dose Pharmaceutical Product. J Pharma Techno Drug Res, 2012, 1, 1-4.

9. Palella FJ, Jr., Delaney KM, Moorman AC, Loveless MO, Fuhrer J, Satten GA, et al.: Declining morbidity and mortality among patients with advanced human immunodeficiency virus infection. HIV Outpatient Study Investigators. N Engl J Med ,1998,338;(13);853-60.

10. Solomon G, Hymete A, Mohamed AMI, Bekhit AA, HPTLC-densitometric method development and validation for simultaneous determination of lamivudine, nevirapine and zidovudine in fixed dose combinations. Thai Journal of Pharmaceutical Sciences, 2010, 35:77-88.

11. PrasadaRao $\mathrm{CH}$ et al, Development and validation of RP-HPLC method for the estimation of Nevirapine in bulk drug and tablets, J. Pharm. Sci. \& Res. Vol.1(2), 2009,78-82.

12. Sahoo. M, Stability indicating RP-HPLC method for determination of nevirapine in pure and tablet form Der Pharma Chemica, 
2013, 5(2):103-110.

13. Ravisankar et al, Development of A New RPHPLC Method For The Estimation Of Nevirapine In Tablet Dosage Form , Int $J$ Pharm Pharm Sci,2013, 5(3) 505-511

14. Pav JW HPLC-UV method for the quantitation of nevirapine in biological matrices following solid phase extraction, J Pharm Biomed Anal. 1999, 20(1-2):91-98.

15. Halde S, Simple, precise and accurate HPLC method of analysis for nevirapine suspension from human plasma. Indian J Pharm Sci.2011, 73(4):416-421.

16. J. V. L. N. SESHAGIRI RAO, A New Validated RP- HPLC Method for the Determination of Nevirapine in Human Plasma, E-Journal of Chemistry, 2010,7(3), 821-826.

17. Kokkula Sandhya, RP-HPLC Method Development And Validation For Simultaneous
Estimation Of Lamivudine, Zidovudine And Nevirapine In Tablet Dosage Form, IAJPR. 2014, 4(4), 2133-2140.

18. S. Dharmaraj Santhosam, Development and Validation of RP-HPLC Method for the Simultaneous Estimation of Lamivudine, Zidovudine and Nevirapine from Bulk and Tablet Dosage Form, International Journal of Pharmaceutical And Chemical Sciences,2013, 2 (4), 1883-1887.

19. PurnimaHamrapurkar, Determination of Nevirapine in Human Plasma by High Performance Liquid Chromatography with Ultraviolet Detection, phamtech,2010,2(2) 1316-1324.

20. Ch Venkata Reddiah, Stability Indicating HPLC Method For Impurities Estimation Of Nevirapine In Extended Release Tablet Dose, Pharmacophore, 2013,4 (2), 50-58. 